\title{
Geochemistry and Organic Contaminants in the Sediments of Great Slave Lake, Northwest Territories, Canada
}

\author{
A. MUDROCH, ${ }^{1}$ R.J. ALLAN ${ }^{1}$ and S.R. JOSHI ${ }^{1}$
}

(Received 20 January 1989; accepted in revised form 27 March 1991)

\begin{abstract}
A study was carried out in the summer of 1987 to determine the geochemistry and distribution of trace elements, PCBs and 16 other chlorinated hydrocarbons in sediments from selected areas in Great Slave Lake, Northwest Territories, Canada. Sediment cores were collected at three sampling stations in the west basin of the lake on a transect from the Slave River delta to the outlet of the Mackenzie River. The geochemical composition of the sediments showed the deposition of similar material at all sampling stations. Sediment dating indicated a very high sedimentation rate $\left(46.6 \mathrm{~g} \cdot \mathrm{cm}^{-2}\right.$ per year) at a $110 \mathrm{~m}$ water depth in the vicinity of the Slave River delta and mixing of bottom sediments at the southwestern part of the lake. The concentrations of trace elements ( $\mathrm{Cu}, \mathrm{Ni}, \mathrm{Co}, \mathrm{Cr}, \mathrm{V}, \mathrm{Pb}$ and $\mathrm{Zn}$ ) were uniform in all sediment profiles. However, surficial sediments were enriched by arsenic. Canadian standard CLB-1 containing 51 PCB congeners was used in the determination of PCBs in the sediment. Thirtythree PCB congeners were detected and their concentrations determined in selected sections of sediment cores. The most abundant congeners were 15 and $18,44,49,52$ and 101 (IUPAC numbering) with maximum concentrations $3.52,2.68,2.44,6.20$ and $2.13 \mathrm{ng} \cdot \mathrm{g}^{-1}$ respectively. The concentration pattern of PCBs in Great Slave Lake sediments indicated considerably greater quantities of lower than higher chlorinated biphenyls. Several congeners, particularly those having 7-10 chlorine atoms, were determined in concentrations smaller than $0.20 \mathrm{ng} \cdot \mathrm{g}^{-1}$ only at one sediment depth. Hexachlorobutadiene, 1,2,3,4-tetrachlorobenzene, pentachlorobenzene, A-HCH, hexachlorobenzene, pentachloroanisol and A-chlordane were present at all stations at different sediment depths. Maximum concentrations of the 16 chlorinated hydrocarbons analyzed in Great Slave Lake sediments were between 0.08 and $1.04 \mathrm{ng} \cdot \mathrm{g}^{-1}$. The concentrations of PCBs and other chlorinated hydrocarbons were about two orders of magnitude lower than those in Lake Ontario sediments.
\end{abstract}

Key words: Great Slave Lake, sediments, geochemistry, PCBs, chlorinated hydrocarbons

RÉSUMÉ. Au cours de l'été de 1987, on a procédé à une étude pour déterminer la géochimie et la répartition des oligo-éléments, des BPC et de 16 autres hydrocarbures chlorés dans des sédiments provenant de zones sélectionnées du Grand Lac de l'Esclave dans les Territoires du Nord-Ouest au Canada. On a prélevé des carottes de sédiments à trois postes d'échantillonnage dans le bassin ouest du lac le long d'un axe allant du delta de la rivière Slave à l'embouchure du fleuve Mackenzie. La composition géochimique des sédiments a révélé un dépôt de matériau similaire à tous les postes d'échantillonnage. La datation des sédiments a montré un fort taux de sédimentation $\left(46,6 \mathrm{~g} \cdot \mathrm{cm}^{-2}\right.$ par an) à $110 \mathrm{~m}$ sous l'eau, dans la zone du delta de la Slave, et un mélange des sédiments de fond dans la partie sud-ouest du lac. Les concentrations d'oligo-éléments $(\mathrm{Cu}, \mathrm{Ni}, \mathrm{Co}, \mathrm{Cr}, \mathrm{V}, \mathrm{Pb}, \mathrm{et} \mathrm{Zn})$ étaient uniformes dans tous les profils de sédiments. Les sédiments de surface cependant contenaient en plus de l'arsenic. On a utilisé des CLB-1 canadiens normalisés contenant 51 congénères de BPC pour déterminer les BPC dans les sédiments. On a détecté 33 congénères de BPC et déterminé leurs concentrations dans des sections choisies des carottes de sédiments. Les congénères les plus abondants étaient les numéros 15 et $18,44,49,52$ et 101 (numérotation de l'IUPAC) avec des concentrations maximales respectives de $3,52,2,68,2,44,6,20 \mathrm{et} 2,13 \mathrm{ng} \cdot \mathrm{g}^{-1}$. Le schéma de concentration des BPC dans les sédiments du Grand Lac de l'Esclave révèle des quantités considérablement plus importantes de biphényles peu chlorés par rapport aux biphényles très chlorés. On a trouvé plusieurs congénères, en particulier ceux ayant de 7 à 10 atomes de chlore, en concentrations

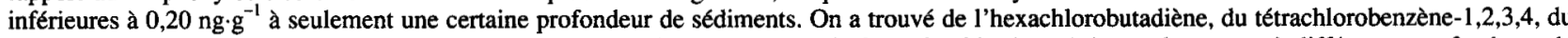
pentachlorobenzène, du H.C.H.-A, de l'hexachlorobenzène, du pentachloroanisole et du chlordane-A à tous les postes à différentes profondeurs de sédiments. Les concentrations maximales des 16 hydrocarbures chlorés analysés dans les sédiments du Grand Lac de l'Esclave se situaient entre 0,08 et $1,04 \mathrm{ng} \cdot \mathrm{g}^{-1}$. Les concentrations de BPC et d'autres hydrocarbures chlorés étaient d'environ deux ordres de grandeur inférieures à celles contenues dans les sédiments du lac Ontario.

Mots clés: Grand Lac de l'Esclave, sédiments, géochimie, BPC, hydrocarbures chlorés

Traduit pour le journal par Nésida Loyer.

\section{INTRODUCTION}

The global cycling and deposition of toxic organic chemicals and metals is well recognized as a major source of such compounds to the environment and, in general, is recognized as a serious concern in North America and Europe. The Chernobyl nuclear incident made it very clear how rapidly chemicals can circumnavigate the earth and be deposited in distant areas. The pollution of the aquatic environment is widespread and occurs in areas without known sources of the contaminants involved. Deposition of many compounds from the atmosphere has been established as a major route for the contamination of marine and freshwater ecosystems in remote areas of the world, including the Canadian Arctic. However, the environmental transport of contaminants is complex and global. For example, many organochlorines are transported by air and water and deposited from air by rain, snow, dry fall-out, and vapourphase deposition.

Chlorinated hydrocarbons have been used, sometimes extensively, in industrialized locations and in agriculture. Nowadays, these persistent organic chemicals have been found in the environment not only at the locations of their use but also in the remote areas of the world, including arctic and Antarctic regions. Although the presence of a few chlorinated hydrocarbons, such as p, $\mathrm{p}^{\prime}$-DDT, p, $\mathrm{p}^{\prime}-\mathrm{DDE}, \mathrm{p}, \mathrm{p}^{\prime}$-DDD, and dieldrin, was discovered in the Canadian Arctic approximately 30 years ago, but mainly in the last decade, improved analytical instruments and procedures enabled successful studies of organochlorines in air, snow, ice, and seawater samples (Hargrave et al., 1988; Patton et al., 1989; Bidleman et al., 1989; Gregor and Gummer, 1989), as well as in the arctic food chain, including polar bears (Norstrom et al., 1988), seals and cod (Muir $e t$ al., 1988), and zooplankton and amphipods (Bidleman et al., 1989).

A study was carried out in the summer of 1987 to determine the geochemistry and concentrations of trace elements, polychlorinated biphenyls (PCBs), and other chlorinated hydrocarbons in sediments from selected areas in Great Slave Lake, Northwest Territories. The objective was to assess the role of the lake in global cycling of contaminants and the 
potential of the lake's sediments for transporting contaminants through the Mackenzie River into the southern Beaufort Sea.

\section{MATERIALS AND METHODS}

\section{Study Area}

Great Slave Lake, with an area of $26900 \mathrm{~km}^{2}$, is a major component of the approximately $6000 \mathrm{~km}$ long Mackenzie River drainage system and the fourth largest lake in Canada (Fig. 1). Maximum depth of the lake is $162 \mathrm{~m}$ in the west and $614 \mathrm{~m}$ in the east basins. Limnology and geological setting of the lake were described by Rawson (1950) and Allan (1979). The Slave River, a $415 \mathrm{~km}$ long major tributary, supplies about $87 \%$ of the total annual discharge to Great Slave Lake (Rawson, 1950). The Slave River combines the contribution of two southern subbasins of the Mackenzie River system, the Athabasca and Peace River basins, and enters the lake by the Slave delta. The lake's only outflow is the Mackenzie River (Fig. 2). Hay River, $700 \mathrm{~km}$ long, Yellowknife River, and a few smaller streams are the other tributaries. The lake stabilizes the flow, water temperature, and water levels of the entire upper Mackenzie River and is a sink for the suspended material discharged by the tributaries, particularly the Slave River, with mean suspended load $30 \times 10^{6}$ ton year $^{-1}$ (Mackenzie River Basin Committee, 1981). The city of Yellowknife, with a population of 11000 , is located on the northern shore of the lake. There are few small towns along the lake's shore. Mining, particularly gold and $\mathrm{Pb}-\mathrm{Zn}$ mines, is the main industry around the lake. However, heavy oil and tar sand deposits and about one million hectares of farmland are in the Athabasca and Peace River areas (Mackenzie River Basin Committee, 1981).

\section{Sediment Sampling and Sample Preparation}

The location of the sampling stations was selected according to the previous investigation of the geochemistry of Great

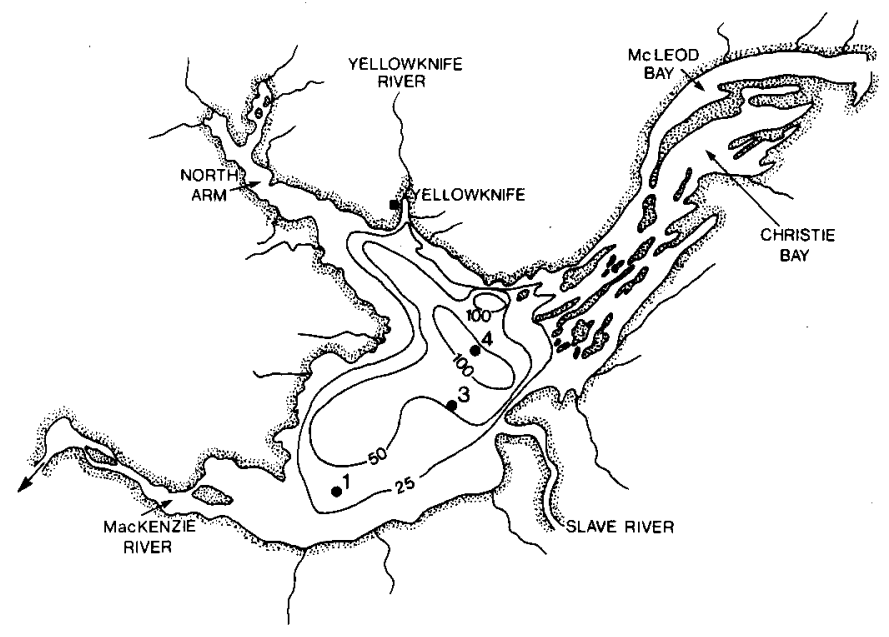

GREAT SLAVE LAKE

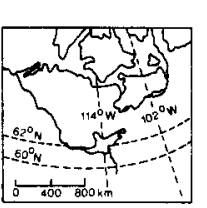

Slave Lake sediments by Allan (1979). To locate fine-grained sediments suitable for coring, the bottom in the vicinity of selected sampling stations was surveyed by echosounding equipment mounted on the vessel. In addition, echosounding was carried out on a line extending from the deepest area in the west basin to the Slave River delta. Fisheries and Oceans vessel Christie Bay, operated by staff members of the Canadian Department of Fisheries and Oceans in Hay River, Northwest Territories, was used for the sampling operation.

Surface sediment samples were obtained by a mini-Ponar grab sampler at five sampling stations. Fine-grained recent sediment suitable for coring was found only at three of the five sampling stations. Five sediment cores were collected at each of these three sampling stations (stations 1, 3, and 4, Fig. 1) using a Benthos corer with a plastic liner. Due to the sediment texture, recovered sediment cores were only 18,25 , and $45 \mathrm{~cm}$ long at stations 1,3 , and 4 respectively. Sediment cores were subsampled into $1 \mathrm{~cm}$ sections (to $20 \mathrm{~cm}$ sediment depth) and into $2 \mathrm{~cm}$ sections (below $20 \mathrm{~cm}$ sediment depth). Subsamples from two cores from each station were placed into hexane-prewashed glass jars for the determination of organic contaminants. Subsamples from three cores from each station were composited into plastic bags for geochemical analyses, dating, and the determination of particle size distribution. All samples in the glass jars were immediately frozen and shipped to the laboratory at the National Water Research Institute, Burlington, Ontario, where they were freeze-dried and used for the determination of organic contaminants. Recently, extensive laboratory testing demonstrated that freeze-drying of sediments does not affect the analyses of PCBs and chlorinated

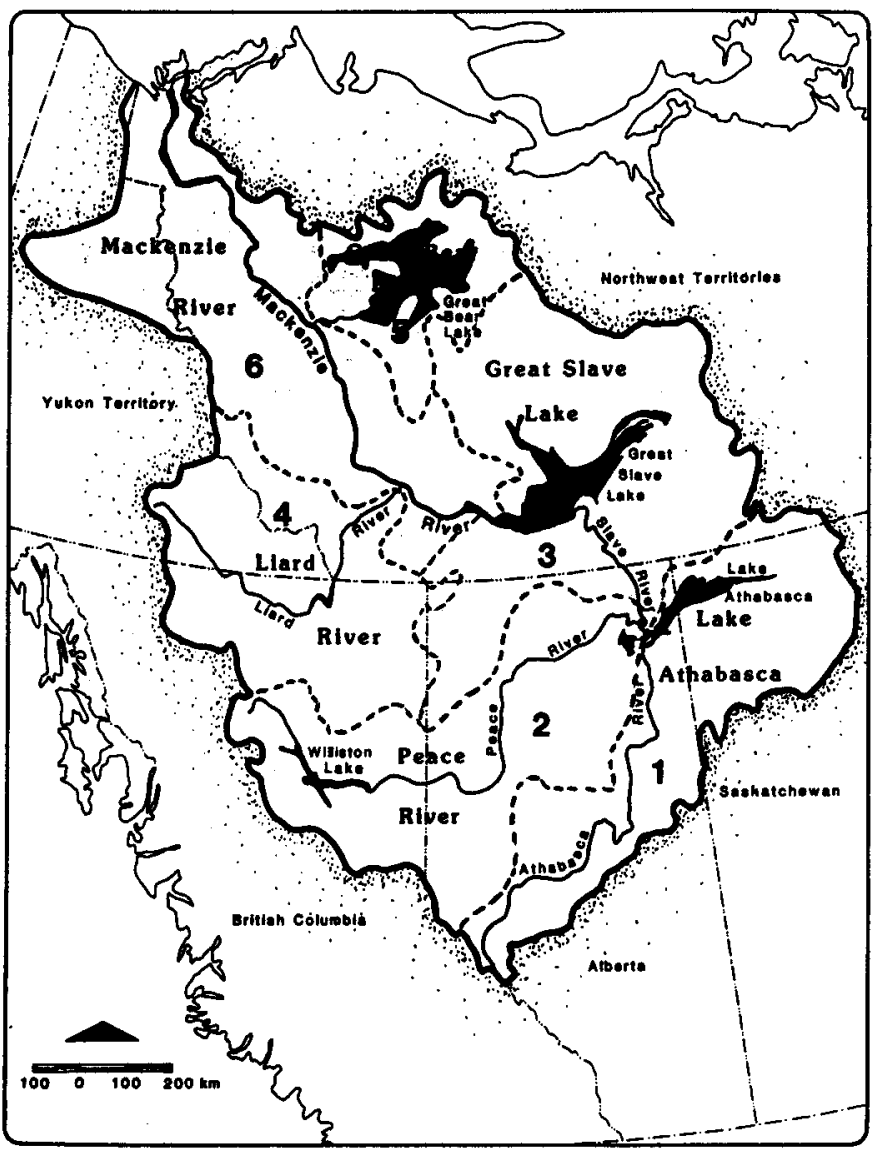

FIG. 2. Drainage subbasins of the Mackenzie River basin. 
hydrocarbons determined in Great Slave Lake sediments (Bourbonniere et al., 1986). One portion of the subsamples composited into plastic bags was used for the particle size analyses and the second portion was frozen, freeze-dried, and homogenized by grinding to $189 \mu \mathrm{m}$ particle size for geochemical analyses.

\section{Chemical Analyses}

Sediment Geochemistry and Metal Concentrations: The concentrations of major elements $(\mathrm{Si}, \mathrm{Al}, \mathrm{Fe}, \mathrm{Ca}, \mathrm{Mg}, \mathrm{K}, \mathrm{Na}$, $\mathrm{Ti}, \mathrm{Mn}$, and $\mathrm{P})$ and trace elements $(\mathrm{Cu}, \mathrm{Cr}, \mathrm{Co}, \mathrm{Pb}, \mathrm{Ni}, \mathrm{V}, \mathrm{Zn}$, and $\mathrm{As}$ ) were determined in all samples by $\mathrm{X}$-ray fluorescence spectrometry using the method described by Mudroch (1985). The precision of the analysis was determined by analyzing five pellets made from a homogenized sediment sample. The accuracy of the analysis was verified by running Canadian Reference Standards Syenite SY-2 and soils SO-2 and SO-4 and comparing the analytical results with the stated reference values for major and trace elements. The concentration of organic $\mathrm{C}$ was determined by Leco carbon analyzer. The mineralogical composition of sediments was investigated by powder X-ray diffraction using $\mathrm{Cu}$-target with a Ni-filter. The particle size distribution was determined by the method described by Duncan and LaHaie (1979).

Chlorinated Hydrocarbons: Chlorinated hydrocarbons were determined in subsamples from the following depths in the cores: $0-1 \mathrm{~cm}, 4-5 \mathrm{~cm}, 5-6 \mathrm{~cm}, 9-10 \mathrm{~cm}$, and $14-15 \mathrm{~cm}$ at each station; $19-20 \mathrm{~cm}$ at station 3 , and $26-28 \mathrm{~cm}$ and $40-42 \mathrm{~cm}$ at station 4.

The analytical procedure for the determination of chlorinated hydrocarbons consisted of $12 \mathrm{~h}$ Soxhlet extraction by dichloromethane. The extracts were subjected to fractionation and precleaning by column chromatography prior to analysis using the method described by Carey and Hart (1986). Each of the resulting fractions was subjected to analyses using a dualcolumn capillary gas chromatography with $30 \mathrm{~m}$ long DB5 and DB17 columns and electron capture detectors. Reproducibility of the analysis on replicate samples was $\pm 10 \%$. Standard material CLB-1A, CLB-1B, CLB-1C, and CLB-1D, a mixture of 51 PCB congeners, used as the standard in the determination of PCBs, was obtained from the Canadian National Research Council, Atlantic Research Laboratory, Halifax, Nova Scotia, Canada. Congener numbers reported in this study correspond to the IUPAC numbering system. Recently, PCB congeners were evaluated by their potential biological significance (Clarke et al., 1989). Moreover, 36 congeners were recommended for use in the regulatory evaluation of PCB-contaminated dredged material and were divided into five groups by their priorities and adverse biological effects attributable to PCBs in the environment. Canadian standard CLB- 1 contains 22 of the 36 congeners selected and grouped by Clarke et al. (1989) - namely, in group 1A congener 77 (absent in the standard are congeners 126 and 169), in group $1 \mathrm{~B}$ congeners $118,128,138,156$, and 170 , in group 2 congeners $87,101,153,180,183$, and 194, in group 3 congeners $18,44,49,52,151,187$, and 201 (absent in the standard are congeners 70,74 , and 177 ), and in group 4 congeners 105,114 , and 189 (absent in the standard are congeners 37 , $81,119,123,157,158,167$, and 168).

The accuracy of the determination of PCBs was confirmed by the analysis of Sediment Reference Material for Total Polychlorinated Biphenyls obtained from Quality Assurance and Method Section, National Water Research Institute, Burlington, Ontario (Lee and Chau, 1987). The accuracy of the determination of specific PCB congeners was confirmed by the analysis of sediment reference materials HS-1 and HS-2 obtained from Canadian National Research Council, Atlantic Research Laboratory, Halifax, Nova Scotia. Hexachloroethane, hexachlorobutadiene, 1,2,3,4-tetrachlorobenzene, pentachlorobenzene, A-HCH, hexachlorobenzene, pentachloroanisole, lindane, heptachlor, heptachlor epoxide, G-chlordane, A-chlordane, dieldrin, $p, p-D D E, p, p^{\prime}-D D D$, and p,p-DDT were determined in the sediment extracts using standards obtained from Polyscience, Niles, Illinois, U.S.A. Gas chromatography-mass spectrometry was carried out on a Hewlett-Packard GC/MS to examine and confirm the presence of individual PCB congeners and the other organochlorines. The presence of individual homologues in sediment samples was confirmed by gas chromatography/mass spectrometry.

\section{Sediment Dating}

The total Pb-210, Ra-226, and Cs-137 levels in the sediment core sections from station 4 were measured by lowenergy gamma-ray spectrometry using techniques described by Joshi (1987a). The contribution of atmospherically delivered or excess $\mathrm{Pb}-210$ (hereafter referred to as $\mathrm{Pb}-210$ ) was obtained by subtracting the amount of $\mathrm{Pb}-210$ supported by $\mathrm{Ra}-226$ from total $\mathrm{Pb}-210$. The sediment age was calculated by the method described previously (Durham and Joshi, 1980; Mudroch and Joshi, 1991; Joshi et al., 1988). Dating of the sediment core collected at station 3 was carried out by the method described by Turner and Delorme (1989).

\section{RESULTS AND DISCUSSION}

\section{Bottom Morphometry and Sediment Geochemistry}

Echosounding revealed a very gentle sloping of the lake bottom from the Hay River mouth towards station 3 (Fig. 1). Echosounding from station 4 (water depth about $110 \mathrm{~m}$ ) towards the Slave River delta (water depth about $20 \mathrm{~m}$ ) showed steep sloping of the bottom from deep water towards the Slave River bar. The steep slope, the configuration of the bottom below the bar, and fine lenses of a darker material in the sediment profile at station 4 suggested sediment slumping and turbidity currents in this part of the lake. The bar at the Slave River mouth was firm, consolidated material, most likely sand.

Generally, the sediments from all sampling stations consisted of very fine grey-brown silty clay, with a surface layer $(1-5 \mathrm{~cm})$ less consolidated than the underlying material. Few amphipods were found at the sediment surface at each sampling station.

The samples contained $77-92 \%$ clay-size particles $(<2 \mu \mathrm{m})$. The rest of the particles were silt (particle size 2-63 $\mu \mathrm{m}$ ). Major minerals were quartz, illite, chlorite, kaolinite, and feldspars. Other minerals in the sediments were calcite and small quantities of many different minerals originating from the complex bedrock geology of the lake drainage basin (Allan, 1979).

The concentrations of major elements were uniform from the surface to the bottom of each sediment core and similar for all three coring stations (Table 1), indicating a continuous deposition of geochemically similar material. Low concentrations of organic $\mathrm{C}$ in the sediment profile indicated the deposition of 
mineral particles and limited contribution of autochtonous organic matter to the sediments in this oligotrophic lake.

All trace elements but As were uniformly distributed in the sediment profiles at all coring stations (Table 2) and represented background concentrations in Great Slave Lake sediments derived from regional geology of the lake's drainage basin. However, As increased in the surficial sediment from 5 to $13 \mu \mathrm{g} \cdot \mathrm{g}^{-1}$ and 6 to $14 \mu \mathrm{g} \cdot \mathrm{g}^{-1}$ at stations 1 and 3 respectively. At station 4 the concentrations of As were uniform (12-14 $\mu \mathrm{g} \cdot \mathrm{g}^{-1}$ ) within a $42 \mathrm{~cm}$ sediment layer. The increase of As in surficial sediments at stations 1 and 3 agreed well with the observations of Allan (1979), who found an increase of As concentrations (up to $14 \mu \mathrm{g} \cdot \mathrm{g}^{-1}$ ) in the sediments at the central west basin of the lake. The source of As enrichment might be effluents or emissions from gold mines on the north shore (Mudroch et al., 1988). Uniform concentrations of As in the sediment profile at station 4 reflected a fast deposition of recent sediment with a greater As content or mixing of the sediments at this area.

\section{Sediment Dating}

Sedimentation rates at station 4 were calculated (Joshi et al., 1988) using two different models: the CIC (constant initial concentration) model assumed both a constant mass flux and a constant excess $\mathrm{Pb}-210$ activity flux at the water/sediment interface, while the CRS (constant rate of supply) model assumed that excess $\mathrm{Pb}-210$ is supplied to the sediments at a constant rate. Both models indicated that the sediment at this area was very young: the $14 \mathrm{~cm}$ sediment section was about 0.23 year of age using both models. The results from both models were virtually the same. When a diffusive mixing parameter was used (Shukla, unpubl. data, 1989), the mixinginfluenced age of the $14 \mathrm{~cm}$ sediment layer was only about 0.02 year. The CIC model gave a mass sedimentation rate of

TABLE 1. Concentration range of major elements in sediments (\% dry weight)

\begin{tabular}{lccc}
\hline \hline Parameter & Station 1 & Station 3 & Station 4 \\
\hline $\mathrm{SiO}_{2}$ & $67.50-68.80$ & $65.70-67.30$ & $66.90-68.40$ \\
$\mathrm{Al}_{2} \mathrm{O}_{3}$ & $16.90-17.50$ & $17.40-18.80$ & $17.10-18.50$ \\
$\mathrm{Fe}_{2} \mathrm{O}_{3}$ & $6.91-7.35$ & $7.02-7.79$ & $5.96-6.67$ \\
$\mathrm{MgO}$ & $1.05-1.15$ & $1.05-1.29$ & $1.56-2.35$ \\
$\mathrm{CaO}$ & $1.65-1.81$ & $1.62-1.77$ & $1.59-1.67$ \\
$\mathrm{Na}_{2} \mathrm{O}$ & $0.60-0.65$ & $0.66-0.68$ & $0.49-0.66$ \\
$\mathrm{~K}_{2} \mathrm{O}$ & $3.05-3.40$ & $3.07-3.38$ & $2.81-3.04$ \\
$\mathrm{TiO}_{2}$ & $0.90-0.95$ & $0.96-1.03$ & $0.94-0.99$ \\
$\mathrm{MnO}$ & $0.09-0.15$ & $0.11-0.34$ & $0.07-0.10$ \\
$\mathrm{P}_{2} \mathrm{O}_{2}$ & $0.15-0.17$ & $0.17-0.19$ & $0.14-0.16$ \\
$\mathrm{O}_{\text {rganic }} \mathrm{C}$ & $1.00-1.25$ & $1.05-1.33$ & $1.25-1.58$ \\
\hline \hline
\end{tabular}

TABLE 2. Concentration ranges of trace elements in sediment $\left(\mu \mathrm{g} \cdot \mathrm{g}^{-1}\right.$ dry weight)

\begin{tabular}{lccc}
\hline \hline Parameter & Station 1 & Station 3 & Station 4 \\
\hline $\mathrm{Cu}$ & $28-31$ & $30-41$ & $20-30$ \\
$\mathrm{Ni}$ & $50-56$ & $50-60$ & $47-52$ \\
$\mathrm{Co}$ & $9-14$ & $8-14$ & $8-15$ \\
$\mathrm{Cr}$ & $110-132$ & $115-141$ & $108-133$ \\
$\mathrm{~V}$ & $168-175$ & $174-184$ & $157-179$ \\
$\mathrm{~Pb}$ & $25-32$ & $27-41$ & $21-30$ \\
$\mathrm{Zn}$ & $132-148$ & $137-150$ & $130-150$ \\
$\mathrm{As}$ & $5-13$ & $6-14$ & $5-14$ \\
\hline \hline
\end{tabular}

about $46.5 \mathrm{~g} \cdot \mathrm{cm}^{-2}$ per year. The Cs-137 activity was detected, although very low compared with the levels of the early 1960s' fallout. Cs-137 activity was detected in the Canadian North earlier (Joshi, 1987b) and its source was considered to be the 1986 nuclear reactor accident in Chernobyl, U.S.S.R. The atypical $\mathrm{Pb}-210$ profile, the morphometry of the bottom, and lenses of different colour material found by the visual inspection of the cores indicated a high sedimentation rate at station 4. Additional dating of a sediment core from station 3 indicated an intensive mixing of the sediment below the surface $3 \mathrm{~cm}$ sediment layer.

An unusually high sedimentation rate at station 4 and sediment mixing at station 3 are most likely due to the input of great quantities of suspended sediments from the Slave River and strong currents at the bottom of the west basin of the lake. The estimated mean sediment inflow from the Slave River into the lake is $30 \times 10^{6}$ tons per year, of which $10 \%$ is sand and the rest is fine-grained material (Mackenzie River Basin Committee, 1981). It is uncertain if all this material becomes deposited on the bottom of the lake, particularly at the area adjacent to the river delta, or is transported through the lake into the Mackenzie River. The dating of sediment core from station 3 and the high concentration of suspended material observed during the sampling period suggested continuous resuspension and transport of some of the material deposited at the southwestern part of the lake.

\section{Organic Contaminants}

PCBs: Detected PCB congeners and their concentrations in the selected sections of sediment cores collected at three stations in Great Slave Lake are shown in Tables 3, 4, and 5. From 51 congeners present in the used standards, 17 congeners were detected in concentrations greater than $0.01 \mathrm{ng} \cdot \mathrm{g}^{-1}$ at station 1 , 35 congeners at station 3 , and 29 congeners at station 4 . The most abundant congeners in the Great Slave Lake samples were $15 / 18,44,49,52$, and 101 . The following maximum concentrations were measured for particular congeners at the

TABLE 3. Concentrations of PCB congeners at different sediment depths at station 1 (in $\mathrm{ng} \cdot \mathrm{g}^{-1}$ dry weight) ${ }^{1}$

\begin{tabular}{lrrrrr}
\hline \hline & \multicolumn{5}{c}{ Sediment depth (cm) } \\
\cline { 2 - 6 } & $0-1$ & $4-5$ & $5-6$ & $9-10$ & $14-15$ \\
\hline $15 / 18$ & 0.32 & 3.07 & 2.44 & 2.12 & 0.91 \\
31 & $<0.01$ & 0.18 & 0.25 & 0.19 & 0.07 \\
40 & 0.22 & 0.07 & 0.11 & 0.11 & 0.08 \\
44 & 0.53 & 0.32 & 0.35 & 0.21 & 0.15 \\
49 & 0.39 & 0.19 & 0.31 & 0.36 & 0.32 \\
52 & 1.74 & $<0.01$ & 0.17 & 0.45 & 0.09 \\
54 & $<0.01$ & 0.29 & 0.47 & 0.23 & 0.28 \\
60 & 0.09 & 0.03 & 0.06 & 0.02 & 0.04 \\
86 & 1.39 & 0.09 & 0.10 & 0.12 & 0.04 \\
87 & 0.26 & $<0.01$ & $<0.01$ & $<0.01$ & $<0.01$ \\
101 & 0.67 & 0.11 & 0.11 & 0.10 & 0.10 \\
118 & 0.21 & 0.05 & 0.04 & 0.04 & $<0.01$ \\
121 & 0.02 & $<0.01$ & 0.03 & 0.02 & $<0.01$ \\
138 & 0.23 & $<0.01$ & $<0.01$ & $<0.01$ & $<0.01$ \\
151 & 0.21 & $<0.01$ & $<0.01$ & $<0.01$ & $<0.01$ \\
153 & 0.15 & 0.05 & 0.03 & 0.01 & $<0.01$ \\
Total & 6.43 & 4.45 & 4.47 & 4.07 & 2.08 \\
\hline \hline
\end{tabular}

Congeners in concentrations $<0.01 \mathrm{ng} \cdot \mathrm{g}^{-1}$ at all sediment depths: 77,103 , $105,114,128,129,137,141,143,154,156,159,170,171,173,180,182$, $183,187,189,191,194,195,196,200,201,202,203,205,206,207,208$ and 209. 
TABLE 4. Concentrations of PCB congeners at different sediment depths at station 3 (in $n g \cdot \mathrm{g}^{-1}$ dry weight) ${ }^{1}$

\begin{tabular}{|c|c|c|c|c|c|c|}
\hline & \multicolumn{6}{|c|}{ Sediment depth $(\mathrm{cm})$} \\
\hline & $0-1$ & $4-5$ & $5-6$ & $9-10$ & $14-15$ & $19-20$ \\
\hline $15 / 18$ & 0.32 & 0.69 & 2.06 & 2.42 & 1.10 & 1.44 \\
\hline 40 & 0.08 & $<0.01$ & 0.14 & 0.10 & 0.08 & 0.10 \\
\hline 44 & 0.34 & 0.04 & 0.13 & 0.23 & 0.35 & 0.23 \\
\hline 49 & 0.29 & 0.09 & 0.28 & 0.58 & 0.28 & 0.19 \\
\hline 52 & 1.67 & $<0.01$ & $<0.01$ & $<0.01$ & $<0.01$ & $<0.01$ \\
\hline 54 & 0.04 & 0.15 & 0.37 & 0.51 & 0.37 & 0.02 \\
\hline 60 & 0.07 & 0.02 & 0.02 & $<0.01$ & $<0.01$ & $<0.01$ \\
\hline 86 & 0.28 & $<0.01$ & 0.04 & 0.09 & 0.09 & 0.10 \\
\hline 87 & 0.23 & 0.14 & 0.03 & 0.09 & 0.12 & 0.23 \\
\hline 101 & 0.58 & $<0.01$ & $<0.01$ & $<0.01$ & $<0.01$ & $<0.01$ \\
\hline 103 & $<0.01$ & $<0.01$ & $<0.01$ & 0.23 & $<0.01$ & $<0.01$ \\
\hline 105 & $<0.01$ & $<0.01$ & $<0.01$ & $<0.01$ & $<0.01$ & 0.05 \\
\hline 118 & 0.18 & $<0.01$ & $<0.01$ & $<0.01$ & $<0.01$ & $<0.01$ \\
\hline 121 & $<0.01$ & $<0.01$ & $<0.01$ & 0.05 & 0.04 & 0.16 \\
\hline 129 & $<0.01$ & $<0.01$ & $<0.01$ & $<0.01$ & $<0.01$ & 0.04 \\
\hline 138 & 0.27 & $<0.01$ & $<0.01$ & $<0.01$ & $<0.01$ & $<0.01$ \\
\hline 141 & 0.03 & $<0.01$ & $<0.01$ & $<0.01$ & $<0.01$ & $<0.01$ \\
\hline 143 & $<0.01$ & $<0.01$ & 0.03 & 0.03 & $<0.01$ & $<0.01$ \\
\hline 151 & 0.17 & $<0.01$ & $<0.01$ & $<0.01$ & $<0.01$ & $<0.01$ \\
\hline 153 & 0.15 & 0.18 & 0.10 & 0.22 & 0.01 & 0.20 \\
\hline 154 & 0.15 & $<0.01$ & 0.02 & 0.04 & 0.04 & 0.04 \\
\hline $156 / 171 / 202$ & $<0.01$ & $<0.01$ & 0.01 & $<0.01$ & $<0.01$ & $<0.01$ \\
\hline 170 & $<0.01$ & $<0.01$ & 0.01 & $<0.01$ & $<0.01$ & $<0.01$ \\
\hline 183 & $<0.01$ & 0.07 & 0.03 & 0.26 & 0.01 & 0.21 \\
\hline 185 & $<0.01$ & $<0.01$ & $<0.01$ & 0.28 & $<0.01$ & $<0.01$ \\
\hline 191 & $<0.01$ & 0.08 & $<0.01$ & $<0.01$ & 0.07 & $<0.01$ \\
\hline 194 & $<0.01$ & $<0.01$ & $<0.01$ & $<0.01$ & $<0.01$ & 0.07 \\
\hline $195 / 208$ & $<0.01$ & $<0.02$ & $<0.01$ & 0.29 & $<0.01$ & $<0.01$ \\
\hline $196 / 203$ & $<0.01$ & $<0.01$ & $<0.01$ & $<0.01$ & 0.11 & 0.01 \\
\hline 201 & $<0.01$ & $<0.01$ & $<0.01$ & $<0.01$ & $<0.01$ & 0.21 \\
\hline Total & 4.55 & 1.46 & 3.45 & 5.52 & 2.67 & 3.30 \\
\hline
\end{tabular}

${ }^{1}$ Congeners in concentrations $<0.01 \mathrm{ng} \cdot \mathrm{g}^{-1}$ at all sediment depths: $31,77,114$, $128,137,159,173,180,182,187,189,200,205,206,207$, and 209.

sampling stations: $15 / 18\left(3.52 \mathrm{ng} \cdot \mathrm{g}^{-1}\right)$ at station $4 ; 44(2.68$ $\left.\mathrm{ng} \cdot \mathrm{g}^{-1}\right)$ at station $4 ; 49\left(2.44 \mathrm{ng} \cdot \mathrm{g}^{-1}\right)$ at station $4 ; 52(6.20$ $\left.\mathrm{ng} \cdot \mathrm{g}^{-1}\right)$ at station 4 ; and $101\left(2.13 \mathrm{ng} \cdot \mathrm{g}^{-1}\right)$ at station 4. PCB congeners detected at all sediment depths at the three sampling stations were: at station $1,15 / 18,40,44,60,86$, and 101 ; at station $3,15 / 18,44,49,54,87$, and 153 ; and at station 4 , $15 / 18,44,49$, and 86 .

In nearly all sediment sections congener 77 was detected by GC-ECD in relatively large concentrations. Since this congener was reported only in a small amount in Aroclor 1242 (Erickson, 1986), its presence and concentrations were suspicious. Consequently, the peak eluting at the position of congener 77 was examined by the GS/MS. The standard of congener 77 was used as the control. In the sample, the main peak was identified as a C22 alkane and the presence of a tetrachlorobiphenyl, particularly congener 77 , was not confirmed. However, the presence of a pentachlorobiphenyl was confirmed but only at a concentration of 0.001 th of the C22 alkane. Consequently, congener 77 was considered among the absent PCBs in Great Slave Lake sediments $\left(<0.01 \mathrm{ng} \cdot \mathrm{g}^{-1}\right.$ in Tables 3 and 6).

The concentrations of the rest of the 51 congeners were lower than $0.01 \mathrm{ng} \cdot \mathrm{g}^{-1}$ at all sediment depths. Furthermore, several congeners, particularly those having 7-10 chlorine atoms, were determined only at one sediment depth. For example, low concentrations $\left(<0.20 \mathrm{ng} \cdot \mathrm{g}^{-1}\right)$ of congeners 114 , $129,137,143,185$, and 200 were determined only at one sediment depth at station 4. The concentration pattern of PCBs in
TABLE 5. Concentrations of PCB congeners at different sediment depths at station 4 (in $\mathrm{ng} \cdot \mathrm{g}^{-1}$ dry weight) ${ }^{1}$

\begin{tabular}{|c|c|c|c|c|c|c|c|}
\hline & \multicolumn{7}{|c|}{ Sediment depth $(\mathrm{cm})$} \\
\hline & $0-1$ & $4-5$ & $5-6$ & $9-10$ & $14-15$ & $26-28$ & $40-42$ \\
\hline $15 / 18$ & 0.32 & 0.30 & 0.24 & 0.33 & 0.27 & 3.52 & 3.25 \\
\hline 31 & $<0.01$ & $<0.01$ & 0.07 & $<0.01$ & $<0.01$ & 1.13 & $<0.01$ \\
\hline 40 & 0.25 & 0.08 & 0.11 & 0.08 & $<0.01$ & $<0.01$ & $<0.01$ \\
\hline 44 & 0.33 & 0.38 & 0.42 & 0.38 & 0.31 & 2.68 & 2.52 \\
\hline 49 & 0.19 & 0.19 & 0.30 & 0.22 & 0.15 & 2.44 & 0.55 \\
\hline 52 & 0.40 & 0.78 & 0.57 & 0.63 & $<0.01$ & 6.20 & 0.37 \\
\hline 54 & $<0.01$ & 0.20 & 0.22 & 0.12 & $<0.01$ & 0.37 & 0.55 \\
\hline 60 & 0.03 & 0.05 & 0.05 & 0.03 & 0.02 & 0.34 & $<0.01$ \\
\hline 86 & 0.09 & 0.11 & 0.12 & 0.08 & 0.08 & 0.72 & 0.12 \\
\hline 87 & 0.03 & 0.10 & 0.11 & 0.11 & $<0.01$ & 0.05 & 0.78 \\
\hline 101 & 0.71 & 0.46 & 0.38 & 0.31 & 0.34 & 2.13 & $<0.01$ \\
\hline 105 & $<0.01$ & $<0.01$ & $<0.01$ & 0.03 & $<0.01$ & 0.03 & $<0.01$ \\
\hline 114 & $<0.01$ & $<0.01$ & $<0.01$ & 0.06 & $<0.01$ & $<0.01$ & $<0.01$ \\
\hline 118 & 0.07 & 0.17 & 0.11 & 0.16 & 0.16 & 0.75 & $<0.01$ \\
\hline 121 & 0.05 & $<0.01$ & 0.06 & $<0.01$ & 0.02 & $<0.01$ & $<0.01$ \\
\hline 128 & $<0.01$ & 0.06 & 0.02 & 0.13 & 0.03 & $<0.01$ & $<0.01$ \\
\hline 129 & $<0.01$ & $<0.01$ & $<0.01$ & 0.06 & $<0.01$ & $<0.01$ & $<0.01$ \\
\hline 137 & $<0.01$ & $<0.01$ & $<0.01$ & 0.02 & $<0.01$ & $<0.01$ & $<0.01$ \\
\hline 138 & 0.07 & 0.18 & 0.11 & 0.21 & 0.09 & 0.40 & $<0.01$ \\
\hline 141 & $<0.01$ & 0.08 & 0.03 & 0.06 & 0.04 & 0.13 & $<0.01$ \\
\hline 143 & $<0.01$ & 0.05 & $<0.01$ & $<0.01$ & $<0.01$ & $<0.01$ & $<0.01$ \\
\hline 151 & 0.15 & 0.16 & 0.12 & 0.26 & $<0.01$ & 0.17 & $<0.01$ \\
\hline 153 & 0.07 & 0.28 & 0.07 & 0.27 & 0.15 & 0.28 & $<0.01$ \\
\hline 183 & $<0.01$ & 0.04 & $<0.01$ & $<0.01$ & 0.06 & $<0.01$ & $<0.01$ \\
\hline 185 & $<0.01$ & $<0.01$ & 0.05 & $<0.01$ & $<0.01$ & $<0.01$ & $<0.01$ \\
\hline $196 / 203$ & $<0.01$ & $<0.01$ & $<0.01$ & 0.04 & $<0.01$ & $<0.01$ & 0.15 \\
\hline 200 & $<0.01$ & $<0.01$ & $<0.01$ & 0.19 & $<0.01$ & $<0.01$ & $<0.01$ \\
\hline Total & 2.76 & 3.67 & 3.21 & 3.78 & 1.72 & 22.29 & 8.29 \\
\hline
\end{tabular}

Congeners in concentrations $<0.01 \mathrm{ng} \cdot \mathrm{g}^{-1}$ at all sediment depths: 77,103 , $154,156,159,170,171,173,180,182,187,189,191,194,195,201,202$, 205, 206, 207, 208, and 209.

Great Slave Lake sediments indicated considerably greater quantities of lower than higher chlorinated biphenyls. In the sediment at station 4 tetrachlorobiphenyls represented $44-60 \%$ of the total PCBs, followed by $8-39 \%$ tri-, 11-28\% penta-, 4$24 \%$ hexachlorobiphenyls, and less than $1 \%$ congeners with $7-10$ chlorine atoms. At stations 1 and 3 tetrachlorobiphenyls represented about $60 \%$ of total PCBs in the surface $1 \mathrm{~cm}$ sediment layer. In the deeper parts of sediment cores dichlorobiphenyls represented $23-47 \%$ of total PCBs, followed by tri- and tetrachlorobiphenyls. Higher chlorinated congeners represented only a small portion of the total PCBs.

In this study, the following congeners recommended for use in the regulatory evaluation of PCB-contaminated dredged material and grouped by their potential for toxicity and occurrence in environmental samples by Clarke et al. (1989) were detected in Great Slave Lake sediments: in group 1B (having enzyme-inducing potential and high-concern toxicity) congeners 118, 128, and 138; in group 2 (less potent as inducers and toxins than the previous group; as a group, they contribute $26-41 \%$ of total PCBs in the bird and animal samples and 7$25 \%$ of total PCBs in fish and invertebrates) congeners 87 , 101,153 , and 183; in group 3 (weak or non-inducers but have numerous reported environmental occurrences or represent at least $10 \%$ composition of total PCB in tissue samples) congeners 18,44, 49, 52, and 151; and in group 4 (mixed-type inducers with low accumulation in animal tissues) congeners 105 and 114.

The predominance of the lower chlorinated PCBs in Great Slave Lake sediments is consistent with the determined PCBs in snow and the investigation of atmospheric transport of 
TABLE 6. Concentration of PCB congeners at different sediment depths in Lake Ontario Eastern Basin (in $\mathrm{ng} \cdot \mathrm{g}^{-1}$ dry weight)

\begin{tabular}{|c|c|c|c|c|}
\hline & \multirow[b]{2}{*}{ * } & \multicolumn{3}{|c|}{ Sediment depth $(\mathrm{cm})$} \\
\hline & & $4-5$ & $14-15$ & $19-20$ \\
\hline $15 / 18$ & 45.55 & 34.32 & 14.52 & \\
\hline 40 & 14.10 & 10.71 & 2.89 & \\
\hline 44 & 59.21 & 47.82 & 13.40 & \\
\hline 49 & 44.22 & 26.91 & 9.12 & \\
\hline 52 & 76.45 & 47.10 & 19.42 & \\
\hline 60 & 16.70 & 27.23 & 1.72 & \\
\hline 86 & 13.65 & 17.70 & 2.56 & \\
\hline 101 & 27.92 & 29.05 & 5.29 & \\
\hline 105 & $<0.01$ & 32.22 & $<0.01$ & \\
\hline 114 & 4.09 & 3.88 & $<0.01$ & \\
\hline 118 & 25.50 & 34.70 & 2.53 & $<0.01$ \\
\hline 128 & 8.59 & 10.12 & $<0.01$ & \\
\hline 129 & 4.99 & 2.77 & $<0.01$ & \\
\hline 137 & $<0.01$ & 6.10 & $<0.01$ & \\
\hline 138 & 17.32 & 27.02 & $<0.01$ & \\
\hline 141 & 2.10 & 7.86 & $<0.01$ & \\
\hline 151 & 6.51 & 5.59 & $<0.01$ & \\
\hline 153 & 17.82 & 25.90 & $<0.01$ & \\
\hline $156 / 171 / 202$ & $<0.01$ & 10.31 & $<0.01$ & \\
\hline 173 & $<0.01$ & 7.72 & $<0.01$ & \\
\hline 180 & 10.95 & 17.30 & 0.24 & \\
\hline 183 & 9.39 & 12.09 & $<0.01$ & \\
\hline 185 & 3.17 & 4.68 & $<0.01$ & \\
\hline 189 & $<0.01$ & 3.55 & $<0.01$ & \\
\hline 191 & 2.37 & 5.16 & $<0.01$ & \\
\hline 194 & 5.84 & 8.23 & $<0.01$ & \\
\hline 201 & 6.63 & 13.70 & $<0.01$ & \\
\hline 205 & 2.27 & $<0.01$ & $<0.01$ & \\
\hline 207 & $<0.01$ & 4.74 & $<0.01$ & \\
\hline 209 & 9.93 & 17.72 & $<0.01$ & \\
\hline Total & 435.26 & 502.20 & 73.81 & $<0.01$ \\
\hline
\end{tabular}

PCBs from warm areas to cold ones. Wet removal of airborne organic pollutants occurs with scavenging of particles by and partitioning of organic vapour into rain and snow (Eisenreich et al., 1981). Following snow melt, organic contaminants are transported by rivers. Data on PCBs in the Laurentian Great Lakes Basin suggest that atmospheric input may represent 60 $90 \%$ of the total PCB input to the lakes. A similar pattern can be assumed for the input of PCBs to the Great Slave Lake basin. The total PCBs were detected in arctic snow in quantities between 0.28 and $1.67 \mathrm{ng} \cdot \mathrm{L}^{-1}$ (Gregor and Gummer, 1989) and between 86 and $1800 \mathrm{pg} \cdot \mathrm{L}^{-1}$ (Bidleman et al., 1989), indicating the transport of these contaminants through the atmosphere.

Monitoring of water quality in the Athabasca River (Fig. 2) revealed detectable concentrations of PCBs. Maximum concentrations of Aroclors 1248, 1254, and 1267 were 0.165, 0.019 , and $0.007 \mu \mathrm{g} \cdot \mathrm{L}^{-1}$ respectively in nonfiltered water from the Athabasca River and 1.70 and $2.40 \mu \mathrm{g} \cdot \mathrm{L}^{-1}$ of Aroclor 1248 and 1260 respectively in water from lakes in the Athabasca River basin (Mackenzie River Basin Committee, 1985). These findings indicate a transport of PCBs into Great Slave Lake via Slave River and its tributaries. In addition to industrial sources in the tributaries' drainage basin, including potential sources at the heavy oil and tar sand deposits, accumulation of PCBs in snow deposited over the winter from the atmosphere most likely contributes to the load during snow melt, which is the period of the largest transport of suspended material by the Slave River into the lake. Therefore the large drainage basin of the tributaries, with its regular snow cover in the winter, has to be considered a potential source of different organochlorines for Great Slave Lake.

The concentrations of PCB congeners determined in the sediment core collected from the deepest depositional basin of Lake Ontario are presented in Table 6 for comparison with PCB congeners detected in Great Slave Lake. From the 51 congeners in the standard, 33 were found in concentrations greater than $0.01 \mathrm{ng} \cdot \mathrm{g}^{-1}$ in Lake Ontario sediments. The concentrations of PCB congeners in Lake Ontario sediments were considerably greater than those in Great Slave Lake sediments (Table 6). Generally, with increasing sediment depth the concentrations of determined PCB congeners decreased in Lake Ontario sediment; the concentrations of many congeners were $<0.01 \mathrm{ng} \cdot \mathrm{g}^{-1}$ at the 14-15 cm sediment depth, and at the 19-21 $\mathrm{cm}$ sediment depth the concentrations of all 51 congeners were $<0.01 \mathrm{ng} \cdot \mathrm{g}^{-1}$. However, the concentrations of at least half of the congeners were greater at the $4-5 \mathrm{~cm}$ depth than those in the $1 \mathrm{~cm}$ surface sediment.

Maximum concentrations of PCBs in sediments collected at three stations in Great Slave Lake and those found in Lake Ontario sediments are shown in Table 7. Radionuclide measurements were used to determine the age of Lake Ontario sediments and historical trends of PCB input to Lake Ontario (Durham and Oliver, 1983). The historical record found in the sediment for PCBs was in good agreement with known production and usage patterns. It showed that the pollution of Lake Ontario with PCBs is still occurring, but to a lesser degree than in the 1960s, and that the input of PCBs to Lake Ontario started around 1930, which corresponds to the commencement of PCB production. Unfortunately, high sedimentation rates and mixing of sediments in Great Slave Lake, determined by sediment dating, made the interpretation of historical inputs of PCBs using concentration profiles in sediments impossible.

Congeners 173,180,189, 205, 207, and 209 were detected in Lake Ontario sediment, but they were not detected in any Great Slave Lake sediment samples. In contrast, the following congeners were detected only in Great Slave Lake sediments, but not in the sediment from Lake Ontario: $31,54,87,103$, $121,143,154,170,203$, and 208. Oliver et al. (1989) and Eisenreich et al. (1989) analyzed PCBs in sediments from Lake Ontario using different standards and procedures. Consequently, there are great differences in specific congener identification and quantification between their work and this study. Clarke et al. (1989) concluded that congener-specific analyses that include a substantial number of PCB congeners are not routinely done, and thus there is not a wealth of data in the literature concerning concentrations of individual congeners in environmental samples.

\section{Other Chlorinated Hydrocarbons}

Concentrations of other chlorinated hydrocarbons determined in different sections of sediment cores at three stations in Great Slave Lake were in the range of $<.01$ to $1.1 \mathrm{ng} \cdot \mathrm{g}^{-1}$ (Tables 8,9, and 10). Maximum concentrations of chlorinated hydrocarbons determined at the investigated stations are shown in Table 11. For comparison, the concentrations of chlorinated hydrocarbons determined in bottom and suspended sediments in Lake Ontario (Oliver and Charlton, 1984; Oliver et al., 1989) are included in Table 11. These are greater than those in Great Slave Lake bottom sediments.

The following organochlorines, listed in approximate order of abundance, were present in all of the analyzed sediment 
TABLE 7. Maximum concentrations of PCB congeners in sediments collected at stations 1, 3, and 4 in Great Slave Lake and Lake Ontario Eastern Basin (in $\mathrm{ng} \cdot \mathrm{g}^{-1}$ dry weight)

\begin{tabular}{|c|c|c|c|c|c|}
\hline \multirow[b]{2}{*}{ EPA group } & \multirow[b]{2}{*}{ PCB congener } & \multicolumn{3}{|c|}{ Great Slave Lake } & \multirow[b]{2}{*}{ Lake Ontario } \\
\hline & & Station 1 & Station 3 & Station 4 & \\
\hline $1 \mathrm{~A}$ & 77 & 2.62 & 1.03 & 1.42 & 40.70 \\
\hline 1B & 118 & 0.21 & 0.18 & 0.75 & 34.70 \\
\hline 1B & 128 & $<0.01$ & $<0.01$ & 0.06 & 10.10 \\
\hline 1B & 138 & 0.23 & 0.27 & 0.13 & 27.00 \\
\hline IB & 156 & $<0.01$ & 0.01 & $<0.01$ & 10.32 \\
\hline 1B & 170 & $<0.01$ & 0.19 & $<0.01$ & $<0.01$ \\
\hline 2 & 87 & 0.26 & 0.23 & 0.78 & $<0.01$ \\
\hline 2 & 101 & 0.67 & 0.58 & 2.13 & 29.10 \\
\hline 2 & 153 & 0.15 & 0.22 & 0.28 & 25.90 \\
\hline 2 & 180 & $<0.01$ & $<0.01$ & $<0.01$ & 17.30 \\
\hline 2 & 183 & $<0.01$ & 0.26 & 0.06 & 12.10 \\
\hline 2 & 194 & $<0.01$ & 0.07 & $<0.01$ & 8.20 \\
\hline 3 & 18 & 3.07 & 2.42 & 3.52 & 45.60 \\
\hline 3 & 44 & 0.53 & 0.35 & 2.68 & 59.20 \\
\hline 3 & 49 & 0.39 & 0.58 & 2.44 & 44.20 \\
\hline 3 & 52 & 1.74 & 1.67 & 6.20 & 76.50 \\
\hline 3 & 151 & 0.21 & 0.17 & 0.26 & 6.50 \\
\hline 3 & 187 & $<0.01$ & $<0.01$ & $<0.01$ & $<0.01$ \\
\hline 3 & 201 & $<0.01$ & 0.21 & $<0.01$ & 13.70 \\
\hline 4 & 105 & $<0.01$ & $<0.01$ & 0.03 & 32.20 \\
\hline 4 & 114 & $<0.01$ & $<0.01$ & $<0.01$ & 4.10 \\
\hline 4 & 189 & $<0.01$ & $<0.01$ & $<0.01$ & 3.66 \\
\hline
\end{tabular}

TABLE 8. Concentrations of chlorinated hydrocarbons at different sediment depths at station 1 (in $\mathrm{ng} \cdot \mathrm{g}^{-1}$ dry weight)

\begin{tabular}{lrrrrr}
\hline & \multicolumn{5}{c}{ Sediment depth (cm) } \\
\cline { 2 - 6 } & $0-1$ & $4-5$ & $5-6$ & $9-10$ & $14-15$ \\
\hline Hexachloroethane & $<0.01$ & $<0.01$ & $<0.01$ & $<0.01$ & $<0.01$ \\
Hexachlorobutadiene & 0.23 & 0.04 & 0.05 & 0.02 & 0.03 \\
1,2,3,4-tetrachlorobenzene & 0.85 & 0.08 & 0.10 & 0.06 & 0.06 \\
Pentachlorobenzene & 1.03 & 0.28 & 0.39 & 0.26 & 0.35 \\
A-HCH & 0.31 & 0.04 & 0.03 & 0.03 & 0.03 \\
Hexachlorobenzene & 1.04 & 0.07 & 0.09 & 0.05 & 0.05 \\
Pentachloroanisol & 0.31 & 0.11 & 0.06 & 0.06 & 0.06 \\
Lindane & $<0.01$ & 0.09 & 0.09 & 0.07 & 0.03 \\
Heptachlor & 0.01 & $<0.01$ & $<0.01$ & $<0.01$ & $<0.01$ \\
Heptachloroepoxide & 0.34 & $<0.01$ & $<0.01$ & $<0.01$ & $<0.01$ \\
G-Chlordane & 0.24 & $<0.01$ & $<0.01$ & $<0.01$ & $<0.01$ \\
A-Chlordane & 0.24 & 0.07 & 0.06 & 0.04 & 0.02 \\
Dieldrin & $<0.01$ & $<0.01$ & $<0.01$ & $<0.01$ & $<0.01$ \\
p,p'-DDE & 0.35 & 0.03 & 0.03 & 0.02 & 0.02 \\
p,p'-DDD & 0.34 & $<0.01$ & $<0.01$ & $<0.01$ & $<0.01$ \\
p,p'-DDT & 0.51 & $<0.01$ & $<0.01$ & $<0.01$ & $<0.01$ \\
\hline \hline
\end{tabular}

samples from three stations in Great Slave Lake: pentachlorobenzene $=1,2,3,4$-tetrachlorobenzene $=$ hexachlorobenzene $>$ A-HCH $>$ pentachloroanisol $>$ hexachlorobutadiene $>$ A-chlordane. The remaining analyzed chlorinated hydrocarbons were not determined in all sediment depths at the three sampling stations. Moreover, although not determined at all sediment depths, hexachloroethane and dieldrin were present only in the sediment from station 4, and p, $\mathrm{p}^{\prime}-\mathrm{DDE}, \mathrm{p}, \mathrm{p}^{\prime}$-DDT, and $\mathrm{p}, \mathrm{p}^{\prime}$ DDD were present at all sediment depths only at this station. Heptachlor was found only in the $1 \mathrm{~cm}$ surface sediment at stations 1 and 3 . In addition to heptachlor, heptachlorepoxide, G-chlordane, $p, p^{\prime}$-DDD, and $p, p^{\prime}$-DDT were only in the $1 \mathrm{~cm}$ surface sediment at station 1 .

The concentration pattern of chlorinated hydrocarbons was similar at stations 1 and 3 , with the greatest concentrations of analyzed compounds generally in the $1 \mathrm{~cm}$ surface sediment. The deeper sediment sections contained considerably lower, but generally similar, concentrations. The concentration pattern of chlorinated hydrocarbons at station 4 was different, with the greatest concentrations of individual compounds at various sediment depths. Generally, the concentrations of determined compounds were similar from the surface to the 42 $\mathrm{cm}$ depth at this station.

Many of the chlorinated hydrocarbons found in the Great Slave Lake sediments may originate from pesticide and herbicide use in the agricultural area of the Canadian prairies and/or atmospheric transport and deposition within the drainage basin. Some are highly resistant to biological, chemical, and thermal degradation. Only limited information is available on the type and quantities of these compounds previously used in the Great Slave Lake and Slave River drainage basins.

Consistent concentrations of A-chlordane in the sediment profile at all three sampling stations reflect an intensive use, high persistency, and atmospheric transport of this compound. Sources and atmospheric transport of insecticide chlordane and its components were discussed by Hargrave et al. (1988), and it was suggested that the major source of chlordane to the atmosphere over the North Atlantic is from the U.S.A. Since the early 1960 s dieldrin was used in North America, but with reduced application in Canada during the 1960s and after 1971. Less volatile and more water-soluble dieldrin tends to be removed from the atmosphere by precipitation and dissolution at the air/water interface of large water bodies. Consequently, this compound is considered a more local contaminant usually associated with riverine/land runoff (Norstrom et al., 1988). In Great Slave Lake sediments dieldrin was found at low concentrations of $0.09 \mathrm{ng} \cdot \mathrm{g}^{-1}$ only at two sediment depths at station 4 , indicating its transport into the lake by the Slave River. Hexachlorobenzene (HCB) was originally used as fungicide in Canada and the U.S.A., but it was also a by-product of some industrial processes (Hallet et al., 1982). HCB was found at all sediment depths in the cores collected in Great Slave Lake. Ottar (1981) noted that HCB was readily transported to northern latitudes from sources farther south. 
TABLE 9. Concentrations of chlorinated hydrocarbons at different sediment depths at station 3 (in $\mathrm{ng} \cdot \mathrm{g}^{-1} \mathrm{dry}$ weight)

\begin{tabular}{|c|c|c|c|c|c|c|}
\hline & \multicolumn{6}{|c|}{ Sediment depth $(\mathrm{cm})$} \\
\hline & $0-1$ & $4-5$ & $5-6$ & 9.10 & $14-15$ & $19-20$ \\
\hline Hexachloroethane & $<0.01$ & $<0.01$ & $<0.01$ & $<0.01$ & $<0.01$ & $<0.01$ \\
\hline Hexachlorobutadiene & 0.17 & 0.04 & 0.05 & 0.04 & 0.08 & $<0.01$ \\
\hline 1,2,3,4-tetrachlorobenzene & 1.00 & 0.19 & 0.16 & 0.10 & 0.10 & 0.27 \\
\hline Pentachlorobenzene & 0.95 & 0.32 & 0.51 & 0.25 & 0.25 & 0.25 \\
\hline $\mathrm{A}-\mathrm{HCH}$ & 0.21 & 0.03 & 0.03 & $<0.01$ & $<0.01$ & 0.62 \\
\hline Hexachlorobenzene & 0.89 & 0.17 & 0.11 & 0.02 & 0.01 & 0.28 \\
\hline Pentachloroanisol & 0.48 & 0.04 & 0.11 & 0.11 & 0.10 & 0.10 \\
\hline Lindane & 0.12 & 0.07 & 0.06 & 0.08 & 0.07 & 0.07 \\
\hline Heptachlor & 0.06 & $<0.01$ & $<0.01$ & $<0.01$ & $<0.01$ & $<0.01$ \\
\hline Heptachloroepoxide & 0.07 & $<0.01$ & $<0.01$ & 0.01 & 0.02 & 0.06 \\
\hline G-Chlordane & 0.08 & 0.02 & 0.02 & $<0.01$ & $<0.01$ & $<0.01$ \\
\hline A-Chlordane & 0.10 & 0.11 & 0.07 & 0.06 & 0.07 & 0.05 \\
\hline Dieldrin & $<0.01$ & $<0.01$ & $<0.01$ & $<0.01$ & $<0.01$ & $<0.01$ \\
\hline $\mathrm{p}, \mathrm{p}^{\prime}-\mathrm{DDE}$ & 0.16 & 0.16 & 0.06 & $<0.01$ & $<0.01$ & 0.05 \\
\hline $\mathrm{p}, \mathrm{p}^{\prime}-\overline{D D D}$ & 0.09 & 0.20 & 0.12 & $<0.01$ & $<0.01$ & 0.17 \\
\hline $\mathrm{p}, \mathrm{p}^{\prime}-\mathrm{DDT}$ & $<0.01$ & 0.25 & 0.18 & 0.08 & $<0.01$ & $<0.01$ \\
\hline
\end{tabular}

TABLE 10. Concentrations of chlorinated hydrocarbons at different sediment depths at station 4 (in $\mathrm{ng} \cdot \mathrm{g}^{-1} \mathrm{dry}$ weight)

\begin{tabular}{|c|c|c|c|c|c|c|c|}
\hline & \multicolumn{7}{|c|}{ Sediment depth $(\mathrm{cm})$} \\
\hline & $0-1$ & $4-5$ & $5-6$ & $9-10$ & $14-15$ & $26-28$ & $40-42$ \\
\hline Hexachloroethane & 0.04 & $<0.01$ & 0.06 & 0.24 & 0.04 & 0.06 & 0.07 \\
\hline Hexachlorobutadiene & 0.14 & 0.04 & 0.17 & 0.12 & 0.16 & 0.20 & 0.14 \\
\hline 1,2,3,4-tetrachlorobenzene & 0.70 & 0.21 & 0.77 & 0.41 & 0.51 & 0.58 & 0.63 \\
\hline Pentachlorobenzene & 0.46 & 0.21 & 0.62 & 0.47 & 0.40 & 0.44 & 0.41 \\
\hline A-HCH & 1.02 & 0.72 & 1.10 & 0.68 & 0.54 & 0.73 & 0.42 \\
\hline Hexachlorobenzene & 0.40 & 0.20 & 0.26 & 0.25 & 0.38 & 0.52 & 0.26 \\
\hline Pentachloroanisol & 0.54 & 0.17 & 0.34 & 0.29 & 0.16 & 0.43 & 0.28 \\
\hline Lindane & 0.23 & 0.10 & 0.17 & $<0.01$ & 0.02 & 0.45 & 0.10 \\
\hline Heptachlor & 0.04 & $<0.01$ & 0.02 & $<0.01$ & $<0.01$ & $<0.01$ & $<0.01$ \\
\hline Heptachloroepoxide & 0.07 & 0.02 & 0.06 & 0.03 & 0.03 & 0.03 & 0.18 \\
\hline G-Chlordane & 0.12 & $<0.01$ & 0.05 & 0.03 & 0.02 & $<0.01$ & 0.07 \\
\hline A-Chlordane & 0.10 & 0.09 & 0.07 & 0.04 & 0.09 & 0.07 & 0.40 \\
\hline Dieldrin & 0.08 & $<0.01$ & 0.09 & $<0.01$ & $<0.01$ & $<0.01$ & $<0.01$ \\
\hline$p, p^{\prime}-D D E$ & 0.11 & 0.09 & 0.11 & 0.07 & 0.06 & 0.19 & 0.21 \\
\hline p,p'-DDD & 0.12 & 0.10 & 0.12 & $<0.01$ & 0.03 & 0.20 & 0.26 \\
\hline $\mathrm{p}, \mathrm{p}^{\prime}-\mathrm{DDT}$ & 0.51 & 0.14 & 0.10 & 0.04 & 0.03 & 0.04 & 0.10 \\
\hline
\end{tabular}

TABLE 11. Maximum concentrations of chlorinated hydrocarbons in sediments collected at stations 1, 3, and 4 in Great Slave Lake and Lake Ontario (in $n g \cdot \mathrm{g}^{-1}$ of dry weight)

\begin{tabular}{|c|c|c|c|c|}
\hline & \multicolumn{3}{|c|}{ Great Slave Lake } & \multirow[b]{2}{*}{ Lake Ontario } \\
\hline & Station 1 & Station 3 & Station 4 & \\
\hline Hexachloroethane & $<0.01$ & 0.02 & 0.24 & ND \\
\hline Hexachlorobutadiene & 0.23 & 0.17 & 0.20 & 12.00 \\
\hline 1,2,3,4-tetrachlorobenzene & 0.85 & 1.00 & 0.72 & 42.00 \\
\hline Pentachlorobenzene & 1.03 & 0.95 & 0.62 & 11.00 \\
\hline A-HCH & 0.31 & 0.62 & 1.10 & 27.00 \\
\hline Hexachlorobenzene & 1.04 & 0.89 & 0.52 & 52.00 \\
\hline Pentachloroanisol & 0.31 & 0.48 & 0.54 & ND \\
\hline Lindane & 0.09 & 0.12 & 0.45 & 0.34 \\
\hline Heptachlor & 0.01 & 0.06 & 0.08 & ND \\
\hline Heptachloroepoxide & 0.34 & 0.07 & 0.18 & ND \\
\hline G-Chlordane & 0.24 & 0.08 & 0.12 & 45.00 \\
\hline A-Chlordane & 0.24 & 0.11 & 0.40 & 45.00 \\
\hline Dieldrin & $<0.01$ & $<0.01$ & 0.09 & ND \\
\hline $\mathrm{p}, \mathrm{p}^{\prime}-\mathrm{DDE}$ & 0.35 & 0.16 & 0.21 & 30.00 \\
\hline $\mathrm{p}, \mathrm{p}^{\prime}-\mathrm{DDD}$ & 0.34 & 0.20 & 0.26 & 20.00 \\
\hline $\mathrm{p}, \mathrm{p}^{\prime}-\mathrm{DDT}$ & 0.51 & 0.25 & 0.16 & 15.00 \\
\hline
\end{tabular}

$\mathrm{ND}=$ not analyzed. 


\section{SUMMARY AND CONCLUSIONS}

Geochemical analyses of sediment cores collected at three stations in Great Slave Lake, Northwest Territories, indicated the deposition of geochemically similar material and uniform concentrations of trace elements except arsenic. The concentrations of arsenic were greater in the surficial sediments than in the rest of the sediment cores from two sampling stations. Thirty-three PCB congeners of the 51 congeners included in the used standard were detected and their concentrations determined in selected sections from sediment cores collected at three stations in Great Slave Lake. The most abundant congeners in analyzed sediments were $15 / 18,44,49,52$, and 101 . The concentration pattern of PCBs in Great Slave Lake sediments indicated considerably greater quantities of lower than higher chlorinated biphenyls. The concentrations of PCB congeners in Lake Ontario sediments were about two orders of magnitude greater than those in Great Slave Lake sediments. Hexachlorobutadiene, 1,2,3,4-tetrachlorobenzene, pentachlorobenzene, A-HCH, hexachlorobenzene, pentachloroanisol, and A-chlordane were present at all analyzed sediment depths from all three sampling stations in Great Slave Lake. The other analyzed chlorinated hydrocarbons were not determined at all stations and all sediment depths. Maximum concentrations of analyzed chlorinated hydrocarbons were 0.08-1.04 $\mathrm{ng} \cdot \mathrm{g}^{-1}$ in Great Slave Lake sediments and were about two orders of magnitude lower than those in Lake Ontario sediments.

It was concluded that Great Slave Lake sediments are a potential storage of chlorinated hydrocarbons that may become transported by sediment resuspension into the Mackenzie River. However, a comprehensive investigation of the distribution of organic contaminants in suspended and bottom sediments from the Slave River-Great Slave Lake-Mackenzie River system would supplement our present limited knowledge of the transport of these persistent toxic contaminants into Canadian subarctic and arctic regions.

\section{ACKNOWLEDGEMENTS}

We would like to thank Mrs. Camilla F. Teixeira for the analyses of chlorinated hydrocarbons in sediments; Mrs. S.P. Thompson for radionuclide analyses; Dr. B.S. Shukla for providing support in $\mathrm{Pb}$ 210 modelling work; Mr. M. Mawhinney for conducting the sampling and logistics support; Mr. B. Olding, IWD, Yellowknife, N.W.T., for his assistance with sampling; Mr. Jim Smith and the cruise members of the vessel Christie Bay, Department of Fisheries and Oceans, Hay River, N.W.T., who provided excellent help by operating the vessel and supplying equipment, which enabled a smooth operation.

\section{REFERENCES}

ALLAN, R.J. 1979. Heavy metals in bottom sediments of Great Slave Lake (Canada): A reconnaissance. Environmental Geology 3:49-58.

BIDLEMAN, T.F., PATTON, G.W., WALLA, M.D., HARGRAVE, B.T., VASS, W.P., ERICKSON, P., FOWLER, B., SCOTT, V., and GREGOR, D.J. 1989. Toxaphene and other organochlorines in Arctic Ocean fauna: Evidence of atmospheric delivery. Arctic 42(4):307-313.

BOURBONNIERE, R.A., VANSICLE, B.L., and MAYER, T. 1986. The Great Lakes sediment bank - I. Burlington, Ontario: National Water Research Institute, Environment Canada. Contribution no. 86-151.

CAREY, J.H., and HART, J.H. 1986. Gas chromatographic/mass spectrometric (GC/MS) identification of the major components of non-aqueous material from the St. Clair River. Water Pollution Research Journal of Canada 21(3):309-322.

CLARKE, J.U., McFARLAND, V.A., and PIERCE, B.D. 1989. Preliminary recommendation for a congener-specific $\mathrm{PCB}$ analysis in regulatory evaluation of dredged material. Vicksburg, Mississippi: Department of the Army,
Waterways Experiment Station, Corps of Engineers. Miscellaneous paper D-89-2. 32 p.

DUNCAN, G.A., and LaHAIE, G.G. 1979. Size analysis procedure used in the Sedimentology Laboratory. Manual, Hydraulics Division. Burlington, Ontario: National Water Research Institute, Department of the Environment.

DURHAM, R.W., and JOSHI, S.R. 1980. Recent sedimentation rates, Pb-210 fluxes, and particle settling velocities in Lake Huron, Laurentian Great Lakes. Chemical Geology 31:53-66.

DURHAM, R.W., and OLIVER, B.G. 1983. History of Lake Ontario contamination from the Niagara River by sediment radiodating and chlorinated hydrocarbon analyses. Journal of Great Lakes Research 9(2):160-168.

EISENREICH, S.J., LOONEY, B.B., and THORNTON, J.D. 1981. Airborne organic contaminants in the Great Lakes ecosystem. Environmental Science \& Technology 15:30-38.

EISENREICH, S.J., CAPEL, P.D., ROBBINS, J.A., and BOURBONNIERE, R. 1989. Accumulation and diagenesis of chlorinated hydrocarbons in lake sediments. Environmental Science \& Technology 23:1116-1126.

ERICKSON, M.D. 1986. Analytical chemistry of PCBs. Stoneham, Massachusetts: Butterworth Publisher. $508 \mathrm{p}$.

GREGOR, D.J., and GUMMER, W.D. 1989. Evidence of atmospheric transport and deposition of organochlorine pesticides and polychlorinated biphenyls in Canadian arctic snow. Environmental Science \& Technology 23:561-565.

HALLET, D.J., NORSTROM, R.J., ONUSKA, F.I., and COMBA, M.E 1982. Chlorinated benzenes in Great Lakes Herring gulls. Chemosphere 11:277-285.

HARGRAVE, B.T., VASS, W.P., ERICKSON, P.E., and FOWLER, B.R. 1988. Atmospheric transport of organochlorines to the Arctic Ocean. Tellus 40B:480-493.

JOSHI, S.R. 1987a. Non-destructive determination of lead-210 and radium226 in sediments by direct photon analysis. Journal of Radioanalytical and Nuclear Chemistry, Articles 116:169-182.

1987b. Early Canadian results on the long-range transport of Chernobyl radioactivity. The Science of the Total Environment 63:125-137.

JOSHI, S.R., SHUKLA, B.S., and McNEELY, R. 1988. The calculation of lead-210 dates for McKay Lake sediments. Journal of Radioanalytical and Nuclear Chemistry, Articles 125:341-349.

LEE, H.-B., and CHAU, A.S.Y. 1987. Analytical reference materials. Part VII. Development and certification of a sediment reference material for total chlorinated biphenyls. The Analyst 112:37-40.

MACKENZIE RIVER BASIN COMMITTEE. 1981. Mackenzie River Basin study report. A report under the 1978-81 Federal-Provincial Study Agreement respecting the water and related resources of the Mackenzie River Basin. Ottawa: Ministry of Supply and Services Canada. 231 p.

1985. Water quality. Mackenzie River Basin study report supplement 9. A report under the 1978-81 Federal-Provincial Study Agreement respecting the water and related resources of the Mackenzie River Basin. Ottawa: Ministry of Supply and Services Canada. 201 p.

MUDROCH, A. 1985. Geochemistry of the Detroit River sediments. Journal of Great Lakes Research 11(3):193-200.

MUDROCH, A., and JOSHI, S.R. 1991. Géochimie et distribution de métaux à l'intérieur de carottes de sédiment prises du lac Saint-Louis (fleuve Saint-Laurent) et datées par radioactivité. Revue des sciences de l'eau 4:1-17.

MUDROCH, A., JOSHI, S.R., SUTHERLAND, D., MUDROCH, P., and DICKSON, K.M. 1988. Geochemistry of sediments in the Back Bay and Yellowknife Bay of Great Slave Lake. Environmental Geology and Water Sciences 14:35-42.

MUIR, D.G.G., NORSTROM, R.J., and SIMON, M. 1988. Organochlorine contaminants in arctic marine food chains: Accumulation of specific polychlorinated biphenyls and chlordane-related compounds. Environmental Science \& Technology 22:1071-1079.

NORSTROM, R.J., SIMON, M., MUIR, D.C.G., and SCHWEINDBURG, R.E. 1988. Organochlorine contaminants in arctic marine food chains: Identification, geographical distribution and temporal trends in polar bears in the Canadian Arctic. Environmental Science \& Technology 22:1063-1070.

OLIVER, B.G., and CHARLTON, M.N. 1984. Chlorinated organic contaminants on settling particulates in the Niagara River vicinity of Lake Ontario. Environmental Science \& Technology 18:903-908.

OLIVER, B.G., CHARLTON, M.N., and DURHAM, R.W. 1989. Distribution, redistribution, and geochronology of polychlorinated biphenyl congeners and other chlorinated hydrocarbons in Lake Ontario sediments. Environmental Science \& Technology 23:200-208.

OTTAR, B. 1981. The transfer of airborn pollutants to the arctic region. Atmospheric Environment 15:1439-1445.

PATTON, G.W., HINCKLEY, D.A., WALLA, M.D., and BIDLEMAN, T.F 1989. Airborne organochlorines in the Canadian High Arctic. Tellus 4IB:243-255. 
RAWSON, D.S. 1950. The physical limnology of Great Slave Lake. Journal of the Fisheries Research Board of Canada 8:3-66.

TURNER, L.J., and DELORME, L.D. 1989. Pb-210 dating of lacustrine sediments from Great Slave Lake (core 148), Northwest Territories. Burlington, Ontario: National Water Research Institute, Environment Canada. Technical Note LRB-89-27. 7 p. 